TITLE:

\title{
RECORD OF TYPHLOTANAIS, A TUBE-BUILDING PARATANAID, FROM SETO (CRUSTACEA : MALACOSTRACA)
}

AUTHOR(S):

Morino, Hiroshi

\section{CITATION:}

Morino, Hiroshi. RECORD OF TYPHLOTANAIS, A TUBE-BUILDING PARATANAID, FROM SETO (CRUSTACEA : MALACOSTRACA). PUBLICATIONS OF THE SETO MARINE BIOLOGICAL LABORATORY 1971, 18(5): 349-354

ISSUE DATE:

1971-01-30

URL:

http://hdl.handle.net/2433/175642

RIGHT: 


\title{
RECORD OF TYPHLOTANAIS, A TUBE-BUILDING PARATANAID, FROM SETO (CRUSTACEA: MALACOSTRACA) ${ }^{1}$ )
}

\author{
HIROSHI MORINO \\ Seto Marine Biological Laboratory
}

With 2 Text-figures

Recently, I was imposed upon by Dr. T. Tokioka of the Seto Marine Biological Laboratory the observation of a single, very small specimen of Tanaidacea as a practical training to get the skill of examining small crustaceans and to enrich my knowledge on them. The specimen had been found by Dr. Tokioka in the sample collected by "Dragonet II" trawled on the 50 meters deep sandy bottom about $1.2 \mathrm{~km}$ west of Cape Setozaki, south of the laboratory on June 13, 1966 (BIERI and Tokioka, 1968). It was interesting that the animal was found hiding itself in a cylindrical nest tube made of fine sand grains, but leaving its posterior half exposed. From GREvE's paper (1967) on the tube-building of some Tanaidacea, it was learned immediately that the specimen might belong to Typhlotanais, a paratanaid genus noted for its habit to build a nest tube. This was confirmed, then, by close examination of the specimen and by checkup of some available references. As the specimen was too small to make an exact drawing in its intact state, appendages were removed after some photographs of the entire animal were taken, examined under the microscope, sketched by using camera lucida, and compared carefully with those of known species of the genus. The dissection of the epistome was unsuccessful.

As will be mentioned later, it may be concluded safely that the specimen is closely allied to Typhlotanais aequiremis (LILLJEBORG) but for the present, decisive identification on a single and juvenile specimen had better be reserved.

Any species of Typhlotanais or any other tube-building forms of Tanaidacea has not been recorded yet in SHIINo's papers dealing with the taxonomy of Tanaidacea of Japan. Moreover in trying exact identification of the present juvenile specimen, some questions have arisen about the specific criteria which have been applied for identification by some previous authors. And it seems to me significant to record all of these. Thus, the following is to show only the details of the specimen and the above-mentioned questions, leaving the general appearance of the specimen to the

1) Contribution from the Seto Marine Biological Laboratory, No. 536 and Studies on Meiobenthos by Dragonet, No. 8.

Publ. Seto Mar. Biol. Lab., XVIII (5), 349-354, 1971. (Article 24) 
descriptions of $T$. aequiremis by SARS (1899).

I would like to express my sincere gratitude to Dr. T. TokıokA for his kindness in offering me this interesting specimen for study. Prof. H. UTinom kindly informed me of some literatures, and Dr. Sh. Fuse, Dr. S. Nishimura and Mr. H. TAnase generously helped me to take photographs of the present very small specimen, my thanks to all these gentlemen are due.

\section{Typhlotanais sp. and its nest tube}

(Figs. 1, 2)

Nest tube: $1.85 \mathrm{~mm}$ in length and $0.35 \mathrm{~mm}$ in diameter measured between the exterior edges of the wall, open at both ends. One end is margined smoothly with mucus, while the opposite end is fringed with sands. The similar appearance of the nest tube is also depicted in the Greve's paper. This obviously shows the growth of the tube at one end, though the actual growing end of the tube can not be decided till a close observation is made on living specimens. However, the posterior part of the body was found exposed out of the tube end fringed with sands, and a smooth edge is seemingly made of mucus secreted from the anterior part of the body by some anterior appendages; then the smoothly edged end might be the growing end. Description of animal: The body is a little longer than $1 \mathrm{~mm}$, almost linear; carapace a quater or fifth as long as body. First free segment of mesosome very short, about a half of following respective segments. Ocular lobe and eye wholly absent. First antenna (fig. $2 \mathrm{~A}$ ) conically attenuated, 3-segmented with middle segment small; the distal segment narrow and tapering to the tip provided with 2 long and 2 short setae, the basal segment longer than distal 2 segments combined. Second antenna (fig. 2 B) rather narrow, a little shorter than 1st antenna, with 2nd segment elongate. Mandible (fig. $2 \mathrm{M}, \mathrm{N}$ ) well developed, cutting edge obscurely dentated, lacinia mobilis only on the left mandible, molar protruded cylindrically. Labrum (fig. 20) with only a pair of lobes. Maxilla 1 (fig. 2 P) with innerlobe and unsegmented palp terminally with 2 long setae. Maxilliped (fig. 2 Q) well developed; palp 4segmented, with some setae on each of three distal segments; epipodite truncate terminally and with one seta. Cheliped (fig. $2 \mathrm{C}$ ) comparatively strong and distally attenuated; hand comparatively narrow and elongate, a little shorter than carpus; dactylus about as long as palm; some papilla-like processes at the proximal region of propodus (fig. 2 D). First pair of pereiopod (fig. $2 \mathrm{E}$ ) much larger than following pairs, ischial segment very short and with a short seta. Three posterior pairs (fig. 2 $\mathrm{H}, \mathrm{I}, \mathrm{J}$ ) robust, with tumefied basal segment, without ischial segment, this segment could not be defined even on the preparations made translucent with carbo-wax. Metasome with 6 segments, medially dilated. Five pairs of pleopods (fig. $2 \mathrm{~K}$ ) well developed. Uropod (fig. $2 \mathrm{~L}$ ) short, biramous; both rami of about the same length, unsegmented; exopodite tapering, but endopodite blunt and with 4 long setae. 
Remarks: The present specimen evidently belongs to the genus Typhlotanais, Family Paratanaidae, and it is regarded as a female, because it is provided with well developed mouth parts and 3-segmented 1st antenna. LANG (1952), after careful examinations of a lot of females of a paratanaid other than Typhlotanais, achieved a generalization
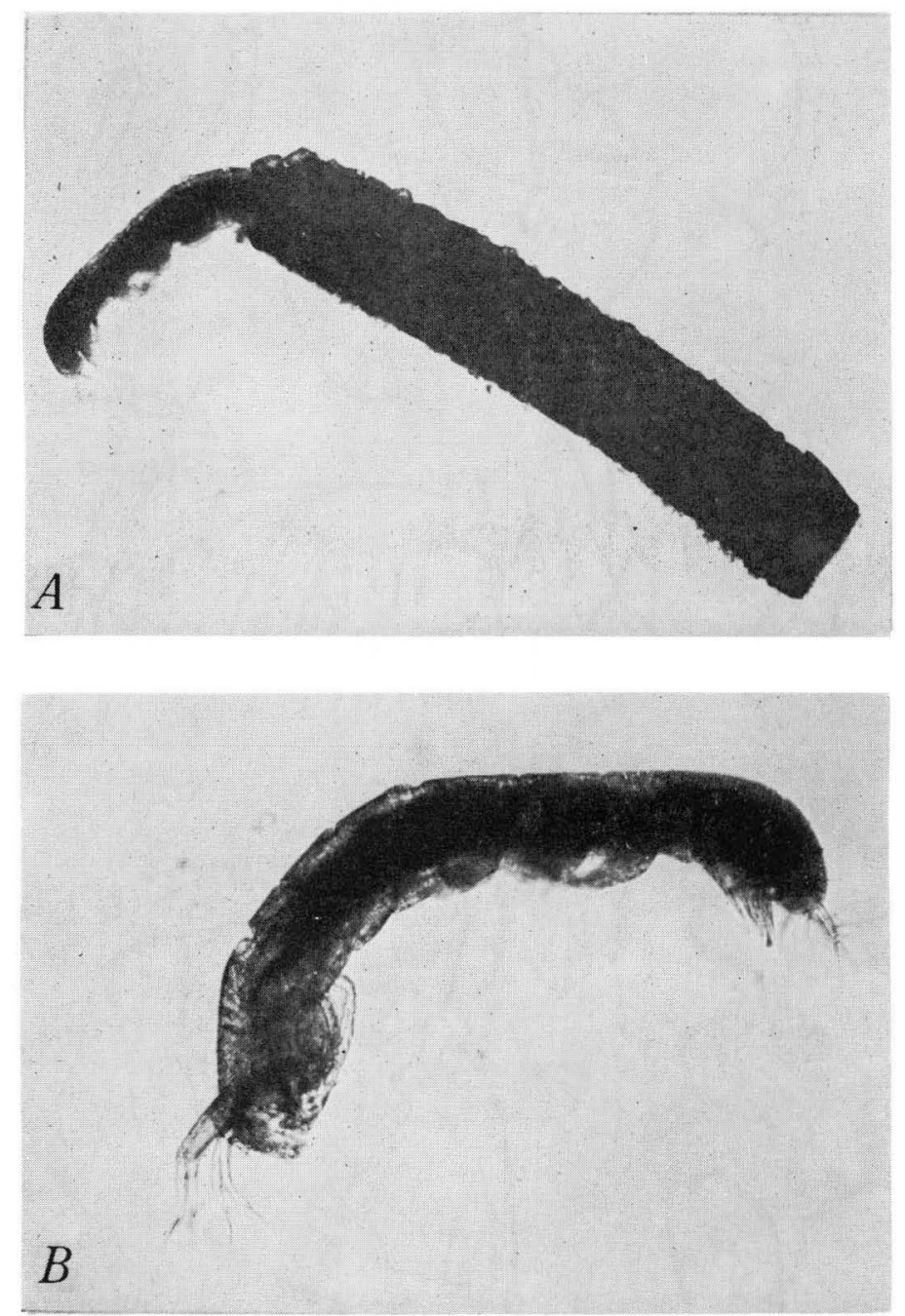

Fig. 1. Typhlotanais sp. A, Nest tube with the posterior part of the animal exposed outside the tube; $\mathrm{B}$, The animal, lateral view; the anterior part is bent down.

of postmarsupial developmental stages. Later, Greve (1965) reported on several species relations between the body length and respective developmental stages that LANG defined. Judging from the small body length, absence of oostegites and pleopods fully developed, the present specimen may well be considered as at the youth stage 

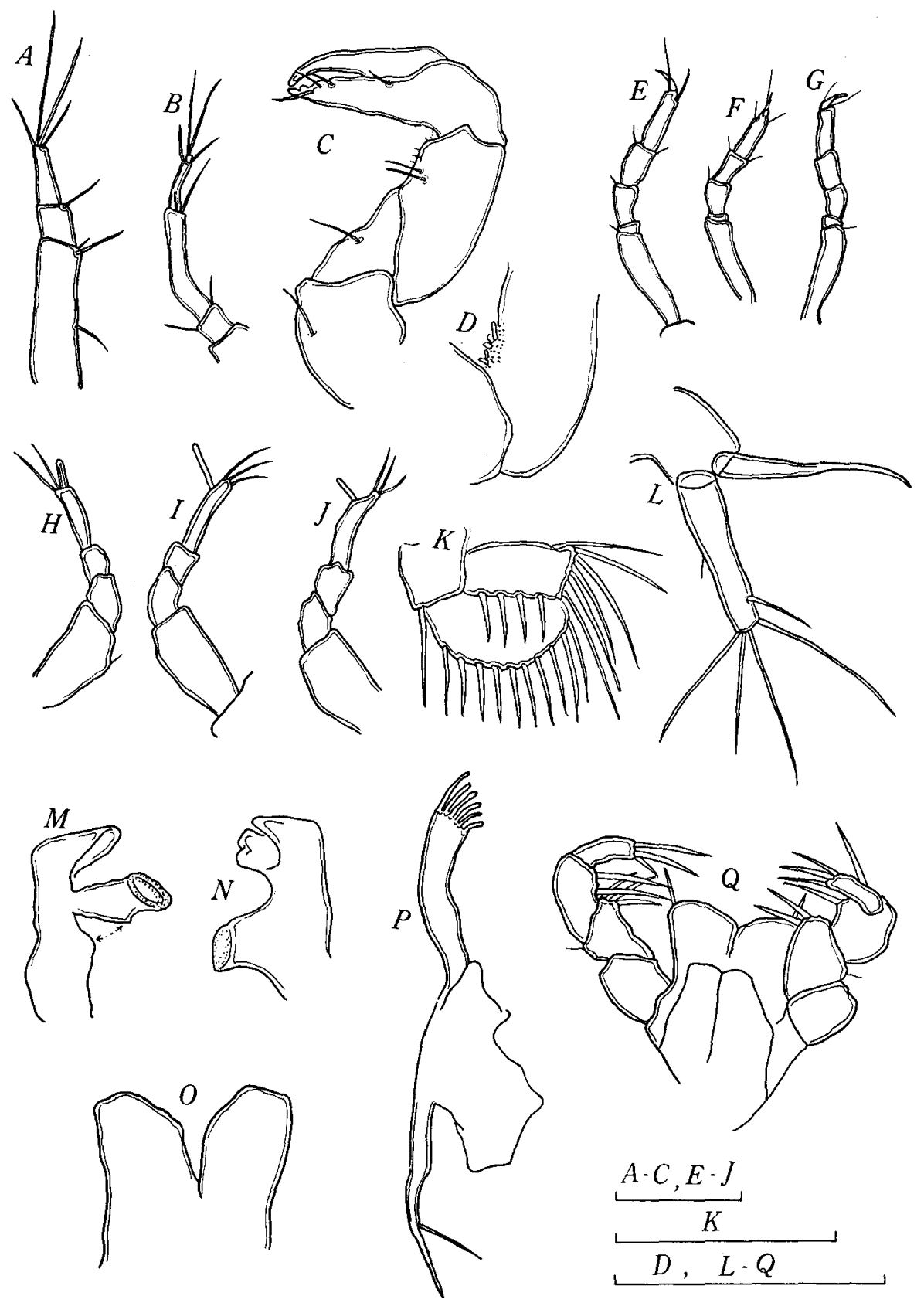

Fig. 2. Typhlotanais sp. A, 1st antenna; B, 2nd antenna; C, cheliped; D, papilla-like processes at the proximal region of the propodus of the same appendage; $E$, 1st pereiopod; $F$, 2nd pereiopod; G, 3rd pereiopod, $\mathrm{H}$, 4th pereiopod; I, 5th pereiopod; J, 6th pereiopod; $\mathrm{K}$, pleop od; L, uropod; M, right mandible with molar process torn at the base; $N$, left mandible; O, labrum; P, 1st maxilla; Q, maxilliped; Three scales show $0.1 \mathrm{~mm}$ respectively. 
sensu LANG. The reason why I could not find the ischial segment on posterior three pereiopods might be attributed to the fixation by alcohol, because LANG (1967) says, "Die Einkerbungen des Propus und Dactylus hängen offenbar davon ab, dass die Tiere in Bouin fixiert waren. Später habe ich alcoholfixiertes Material ..... bekommen. Bei diesen Exemplaren kommen keine Einkerbungen vor."

So far the descriptions of 29 species of the genus Typhlotanais are available to me to be compared with the present specimen, though those of some species were referred to through the descriptions of other species; for example, T. proctagon TATTERSAL was learned through LANG's remarks given as to $T$. peculialis LANG.

Because of their different body shape, the following 11 species are to be excluded from the comparison: T. brevicornis (LILLJEBORG), cornutus G.O. SARs, macrocephala Hansen, irregularis Hansen, variabilis Hansen, grandis Hansen and solidus Hansen. Because of their much slenderer or longer cheliped, the following 5 species are imcomparable with the present specimen: microchelus G.O. SARS, assimilis G.O. SARS, penicillatus G.O. SARs, inaequipes Hansen and kerguelensis F.E. Beddard. Next seven species have respectively unique specific characters which the present specimen does not share: tenuimanus (LiLlJEBORG), tenuicornis G.O. SARs, trispinosus HANSEN, proctagon TAtTersal, spinicauda Hansen, plebejus HANsen and peculialis LANG. T. finmarchicus G.O. SARs, mixtus HANSEN and brachyurus F.E. BEDDARD have each similarly the pereiopod II as long as pereiopod I. In T. inermis HANSEN and profundus HANSEN, the carapace is shaped differently from the present specimen. Thus lastly $T$. aequiremis (LILLJEBorg) is found situated very near the present specimen. There still remains a question about the difference of the segmentation of the uropod between $T$. aequiremis and the present specimen. SARs assigned a high weight to the morphology of uropod. SHino (195la), however, showed that the geographical variations were seen in the number of segments of uropods in Tanais cavolinii (M-EDwARDs) of the family Tanaidae and that in treating Leptochelia dubia $\left(\mathrm{K}_{\mathrm{R} \phi \mathrm{YER}}\right)$ of family Paratanaidae, it was impossible to distinguish the species of the genus Leptochelia only by the number of segments of uropod. LANG presented a case of paratanaid of a certain undetermined genus other than Typhlotanais, which increased the number of segments of uropod by one at two times respectively in manca and youth stages. On the other hand, Greve (1965) identified 3 species of Typhlotanais on very small specimens as $0.6 \mathrm{~mm}$ in body length. For instance, she collected 255 specimens of $T$. aequiremis, 0.65 to $3.4 \mathrm{~mm}$ long, and showed an easy way to distinguish them from other species. According to her, "The female can be identified by the form of the uropods with exopods 2 jointed, the endopods about the same length." She remarked the development of the last pair of pereiopods and pleopods in specimens longer than $1.15 \mathrm{~mm}$, but stated in the discussion, "During growth, the specimens change quite a bit, and sometimes these manca stages can be difficult to determine." May her remarks be taken to show that the number of segments of uropod is never changed during the growth, at least in Typhlotanais? But, it is not unnatural to suppose further segmentation of 
uropod. Then, the present specimen seems to be most closely allied to T. aequiremis (LILLJEBORG).

\section{REFERENCES}

BEDDARD, F.E. 1886. Report on the Isopoda collected by H.M.S. Challenger during the year 1873-76. Report on the scientific results of the exploring voyage of H.M.S. Challenger. Zoology, Vol. 17.

BIERI, R. and T. Tokioks 1968. Dragonet II. An opening-closing quantitative trawl for the study of microvertical distribution of Zooplankton and Meio-Epiqenthos Publ. Seto Mar. Biol. Lab., Vol. 15, No. 5, pp. 373-390.

Greve, L. 1965. The biology of some Tanaidacea from Raunefjorden, western Norway. Sarsia, No. 29, pp. 43-54.

- 1967. On the tube building of some Tanaidacea. Ibid. No. 29, pp. 295-298.

HANSEN, H.J. 1913. Crustacea Malacostraca, II. Danisch Ingolf-Expedition. Vol. 3.

LANG, K. 1949. Contribution to the systematics and synonymics of the Tanaidacea. Ark. Zool. Bd. 42 A, No. 18, pp. 1-14.

1952. The postmarsupial development of the Tanaidacea. Ibid. 2nd Ser. Bd. 4, No. 18, pp. $409-422$.

-_ 1967. Taxonomische und phylogenetische Untersuchung über die Tanaidacean. 3. Ibid. Bd. 19, No. 18, pp. 343-368.

_ 1968. Deep-Sea Tanaidacea. Galathea Report, Vol. 9.

SARS, G.O. 1899. An Account of the Crustacean of Norway. Vol. II, Isopods, Bergen.

Shrrno, S.M. 1938. On Apseudes nipponicus n. sp. (Crustacea, Tanaidacea). Annot. Zool. Japon. Vol. 16 , pp. 53-62.

- 1951a. Notes on three species of Tanaidae from Japanese Coast. Misc. Rep. Res. Inst. Nat. Res. Nos. 19-38, pp. 32-38.

1951b. On two new species of the family Apseudidae found at Seto. Rep. Fac. Fish. Pref. Univ. Mie, Vol. 1, pp. 12-25.

-_ 1952. A new genus and two new species of the order Tanaidacea found at Seto. Publ. Seto Mar. Biol. Lab., Vol. 2, No. 2, pp. 4-28.

P.S. Just recently it was found that R.K. Kudinova-PAsternak established 7 new species, angularis, rectus, compactus, setosus, magnificus, kussakini and longictphala, of Typhlotanais in her three papers dealing with tanaidaceans collected by the Vitjaz from the Bougainville Trench (1965), the Pacific ultraabyss (1966) and the Kurile-Kamchatka Trench and its environment (1970). If the uropod in my specimen remains unsegmented in adult, it must be allied to kussakini more closely than to aequiremis in sharing the ischium of the anterior 3 pereiopods lacking a long hair, the peduncle of the 2nd antenna lacking hooks, and the exopodite and endopodite of the uropod both unisegmented. Three strong spines on the propodus of pereiopods and 2 or 3 strong denticles on the lower ridge of the mandibular molar, described in kussakini, were not found in my specimen. The habitat of kussakini, 5000-6000 $\mathrm{m}$ of the Kurile-Kamchatka Trench, differs so much from that of my specimen, but this might not be decisive, as very eurybathic tanaidaceans are known.

Kudinova-Pasternak, R.K. 1965: Deep sea Tanaidacea from the Bougainville Trench of the Facific. Crustaceana, vol. 8, no. 1, pp. 75-91. 1966: Tanaidacea (Grustacea) of the pacific ultra-abyssals. Zool. Zh. vol. 45, no. 4, pp. 518-535. 1970: Fauna of the Kurile-Kamchatka Trench and its environment. Trudy Inst. Okeanol., vol. 86 . 